\title{
Analysis of Factors Affecting Pregnant Women to Perform Perineal Massage
}

\author{
Aidha Rachmawati ${ }^{1}$, Rizka Esty Safriana ${ }^{2}$, Endah Mulyani $^{3}$, Siti Mudlikah ${ }^{4}$, \\ Luluk Yuliati ${ }^{5}$ \\ ${ }_{1,2,3,4,5}$ Lecturer of Midwifery, University of Muhammadiyah Gresik \\ aidha.rachmawati@umg.ac.id
}

\begin{abstract}
One of the fears that is often felt by third trimester pregnant women is perineal rupture during childbirth. Perineal rupture can be prevented by taking preventive measures during pregnancy, namely perineal massage which can be done by pregnant women from 34 weeks of gestation until nearing labour. In East Java, the maternal mortality rate in 2018 was 515 per year or 1 to 2 people per day. The cause of the high maternal mortality rate of $20.3 \%$ is due to postpartum haemorrhage. The purpose of this study was to analysis the factors that influence pregnant women to perform perineal massage. The total population was 120 pregnant women with a sample of 92 pregnant women in April-July 2019, the sampling technique used simple random sampling. The data analysis used multiple logistic regression statistical tests while the significance test used a 0.05 degree of error. The results of this study were the age factor with a low risk of affecting pregnant women, the p-value was 0.003 $(<0.05)$. Knowledge and motivation factors have an effect together. Knowledge has an effect of 122.5 times while motivation has an effect of 13.14 times in doing perineal massage during the third trimester of pregnancy. Health workers are encouraged to increase socialization and approach to third trimester pregnant women so that they want to do perineal massage independently
\end{abstract}

\section{Introduction}

Every pregnant woman is expected to routinely do antenatal care checks to avoid complications and complications. Pregnant women will experience physiological changes which sometimes require several therapies and exercise methods so that the process runs smoothly. Every day as many as 830 mothers in the world die or as many as 38 mothers in Indonesia die every day due to diseases / complications experienced during pregnancy or childbirth.[1] In East Java, the maternal mortality rate in 2018 was 515 per year or 1 to 2 people per day.[2] The cause of the high maternal mortality rate as much as $20.3 \%$ is due to postpartum bleeding. Postpartum haemorrhage is caused by many factors, one of which is due to perineal rupture. Perineal rupture is a tear or injury to the perineum due to childbirth. Perineal rupture can occur because of a spontaneous tear or because of an episiotomy. Perineal rupture can be prevented by taking preventive measures during pregnancy, namely perineal massage which can be done by pregnant women from 34 weeks of gestation until nearing labour.[3] Perineal massage is useful for softening connective tissue, improving blood circulation, and as a relaxation. Perineal massage is very easy to do, this procedure can be done every day and can even be done alone without the need for help from others.

The results of a study conducted by mothers with gestational age of 36 weeks and over showed that perineal massage can reduce the incidence of spontaneous perineal rupture. [4] The results of this study are also in line with other studies that perineal massage is able to prevent perineal 
rupture in labouring mothers.[5] Pregnant women who have received knowledge and information about the benefits of perineal massage do not necessarily want to do regular massage because it is related to the health behaviour of pregnant women. A person's health behaviour is determined by 3 factors, namely predisposing factors, supporting factors, and driving factors. Predisposing factors are manifested in knowledge, attitudes, traditions, beliefs, beliefs, values, education, and so on. Enabling factors are manifested in the physical environment, available or unavailability of facilities or health facilities, for example health centre, medicines, and equipment. Reinforcing factors are manifested in the attitudes and behaviour of community leaders, religious leaders, health workers, or other officers, which are the reference group for community behaviour.[6]

\section{Methods}

\subsection{Regional and Periods}

Study The research was carried out in the village of Baruh, Sampang District, Sampang Regency from February to July 2019. Baruh Village is one of 12 villages and 6 sub-districts in the Sampang sub-district with an area of $5.40 \mathrm{~km} 2$. The location of the village of Baruh, Sampang Subdistrict, is very strategic, where in the east it is bordered by Camplong District, in the south by the Madura Strait, to the north by Kedungdung District, and to the west by Torjun District. The distance between Baruh village and the Puskesmas health facility in the Sampang sub-district is only $1 \mathrm{~km} 2$. The total population of Baruh village is 4,500 people with a total of 450 family heads.

\subsection{Study design and population}

This research method is analytic with an approach cross-sectional. The population in this study were all pregnant women in the third trimester with gestational age criteria of 34 weeks and over in the working area of the Kamoning Community Health Centre, Sampang District, Sampang Regency, as many as 120 pregnant women. The sample in this study was 92 pregnant women in April-July 2019 with the determination of the sample size using the simple random sampling method.

\subsection{Data collection procedures Data}

Collection was collected through a structured interview method with a closed questionnaire. The type of data collected in this study is secondary data, namely data that comes from pregnant women. Interviewers visit homes for approval then conduct interviews for data collection.

\subsection{Measurement of}

Knowledge. The knowledge variable about Perineal Massage was measured using 10 questions containing 7 positive questions and 3 negative questions. "Correct" answers get a score of 1 , while for "wrong" answers a score of 0 is then totaled. The results will be grouped into 2 categories: good knowledge (answered correctly> 5 questions); and lack of knowledge (answered correctly $\leq 5$ questions).

Motivation. Motivation in performing perineal massage was measured using 10 statements. Statements on the Motivation variable consist of 2 types of statements, namely 6 positive statements and 4 negative statements. Motivation variables will be grouped into 2 categories; low motivation then the score is 0 ; and high motivation score 1

Perineal massage. The desire to do perineal massage is divided into 2 categories; does not do then the score is 0 ; and do then score 1

Age. Age is grouped into two categories. If the age at low risk (age $\leq 30)$ score 0 ; and if age at high risk (age> 30) a score of 1 
Education. Education is classified into two categories. If low education is at the level of SD / SMP / SMA or equivalent, the score is 0 , if higher education is at the level of academy / tertiary education then the score is 1 .

Job. Jobs are divided into two categories. If you don't work, then the score is 0 , if you work, then the score is 1 .

2.5 Management and data analysis.

In this study, data analysis was carried out univariate, bivariate, and multivariate using multiple logistic regression statistical tests.[7] While the significance test uses a degree of error of 0.05 , then all data obtained is processed with the help of computerized tools.

\section{Results and discussion}

3.1 Subject characteristics

A total of 92 research subjects were interviewed. The frequency distribution of the characteristics of the research subjects is described in Table 1. It is known that the age of the respondents is low risk as much as 68 (73.9\%), the education level of the respondents is high education as much as $54(58.7 \%)$, most of the respondents are women who do not work as much as $57(62 \%)$, the respondents 'knowledge was good as much as $56(60.9 \%)$ and the respondents' motivation in doing perineal massage was classified as high motivation as much as 54 (58.7\%), and most of the respondents did perineum massage as much as $57(62 \%)$.

Table 1. Characteristics of Study Subjects

\begin{tabular}{lcc}
\hline \multicolumn{1}{c}{ Variable } & Frequency (n) & Percentage (\%) \\
\hline Age & & \\
Low Risk & 68 & 73,9 \\
High Risk & 24 & 26,1 \\
\hline Education & & \\
Low Education & 38 & 41,3 \\
Higher Education & 54 & 58,7 \\
\hline Work & & \\
Not Working & 57 & 62 \\
Working & 35 & 38 \\
\hline Knowledge & & \\
Knowledge is less & 36 & 39,1 \\
Good Knowledge & 56 & 60,9 \\
\hline Motivation & & \\
Low & 38 & 41,3 \\
High & 54 & 58,7 \\
\hline Perineal Massage & & \\
Do Not & 35 & 62 \\
Doing & 57 & \\
\hline
\end{tabular}

3.2 The results of the bivariate test to massage the perineum

In table 2 shows the relationship between age, education, occupation, knowledge, motivation, and massage the perineum 
Table 2. The results of the bivariate test to massage the perineal

\begin{tabular}{|c|c|c|c|c|c|c|c|c|}
\hline \multirow{3}{*}{$\begin{array}{l}\text { Independent } \\
\text { Variables }\end{array}$} & \multicolumn{4}{|c|}{ Perineum Massage } & \multicolumn{2}{|r|}{ Total } & \multirow[t]{3}{*}{ P value } & \multirow[t]{3}{*}{ OR } \\
\hline & \multicolumn{2}{|c|}{ Do } & \multicolumn{2}{|c|}{ Doing } & \multirow[t]{2}{*}{$\mathbf{n}$} & \multirow[t]{2}{*}{$\%$} & & \\
\hline & $\mathbf{n}$ & $\%$ & $\mathrm{n}$ & $\%$ & & & & \\
\hline \multicolumn{9}{|l|}{ Age } \\
\hline Low Risk & 34 & $50 \%$ & 34 & $50 \%$ & 68 & 100 & 0,003 & 23,00 \\
\hline High Risk & 1 & $4,2 \%$ & 23 & 95,8 & 24 & 100 & & \\
\hline \multicolumn{9}{|l|}{ Educatin } \\
\hline Low Education & 25 & 65,8 & 13 & 34,2 & 38 & 100 & 0,000 & 8,462 \\
\hline Education Higher & 10 & 18,5 & 44 & 81,5 & 54 & 100 & & \\
\hline \multicolumn{9}{|l|}{ Work } \\
\hline Not Working & 14 & 24,6 & 43 & 75,4 & 57 & 100 & 0,001 & 0,217 \\
\hline Working & 21 & 60 & 14 & 40 & 35 & 100 & & \\
\hline \multicolumn{9}{|l|}{ Knowledge } \\
\hline Knowledge Less & 32 & 88,9 & 4 & 11,1 & 36 & 100 & 0,000 & 141,33 \\
\hline Good Knowledge & 3 & 5,4 & 53 & 94,6 & 56 & 100 & & \\
\hline \multicolumn{9}{|l|}{ Motivation } \\
\hline Low & 30 & 78,9 & 8 & 21,1 & 38 & 100 & 0,000 & 36,750 \\
\hline High & 5 & 9,3 & 49 & 90,7 & 54 & 100 & & \\
\hline
\end{tabular}

3.3 Effect of independent variables in performing perineal massage

Table 3. Results of multivariate analysis did perineal massage

\begin{tabular}{lcc}
\hline \multicolumn{1}{c}{ Independent Variables } & Sig & OR \\
\hline Maternal Age & 0,998 & 0,663 \\
Education & 0,599 & 2,113 \\
working & 0,998 & 0,000 \\
Knowledge & 0,003 & 122,509 \\
Motivation & 0,039 & 13,139 \\
\hline
\end{tabular}

Based on table 3 it can be seen that the only variable knowledge and motivation which has the influence together, namely with a value of $=0.003$ for knowledge and for motivation with a value of $=0.039$. The mother's knowledge gave an effect of 122.5 times while the mother's motivation had an effect of 13.14 times in doing perineal massage during the third trimester of pregnancy.

\subsection{Discussion}

This study analysis the factors that influence pregnant women to perform perineal massage. The choice to do massage on the perineum is associated with factors of knowledge, motivation, age, education, and occupation of pregnant women. There is no significant relationship between education and work.

Based on the results of this study, it shows that the knowledge factor and the motivation factor are the factors that most determine a pregnant woman to perform perineal massage. Mothers with good knowledge were 122.5 times more likely to perform perineal massage. Good knowledge because pregnant women receive counselling from village midwives and health 
workers about perineal massage. Good knowledge because pregnant women receive counselling from village midwives and health workers about perineal massage. Knowledge of pregnant women about perineal massage can minimize the incidence of perineal rupture. One of the efforts to prevent perineal rupture is to provide health education about perineal massage to increase maternal knowledge about perineal massage. Health education is one of the competencies demanded by health workers, because it is one of the roles that must be carried out in every effort to improve health wherever it is assigned, both for individual patients, groups and communities.[8]

The results of this study also revealed that motivation was a factor influencing pregnant women to perform perineal massage. The results of data analysis showed that maternal motivation had an effect of 13.14 times in performing perineal massage. Motivation is a stimulus or impulse related to awakening something. Positive motivation can be influenced by the mother having the opportunity and the availability of the means to do perineal massage as well as support from family and loved ones who encourage pregnant women.[9]

Other factors from this study such as age, education, and occupation of pregnant women were not proven to influence pregnant women to perform perineal massage. Even so, it still cannot be ignored, giving the correct information about perineal massage to pregnant women. It is necessary for this health worker to explain to pregnant women so that they know the benefits of perineal massage.

Perineal massage is very safe and harmless and can protect perineal function for at least 3 months after delivery.[7][10] According to researchers, perineal massage has various advantages, all of which are aimed at reducing the incidence of trauma during childbirth. The advantages include stimulating blood flow to the perineum which will help speed up the healing process after childbirth, helping the mother to relax more during vaginal examinations (Vaginal Touch), helping to mentally prepare the mother for perineal pressure and strain when the baby's head will come out and avoiding an episiotomy.[11]

\section{Conclusion}

The factors that most influence pregnant women in performing perineal massage in Baruh village are the mother's knowledge and motivation. Mother's knowledge gave an effect of 122.5 times, while mother's motivation was 13.14 times. For other factors such as age, education, and occupation were not proven to significantly influence pregnant women in performing perineal massage.

\section{References}

[1] E. L. Achadi, "Kematian Maternal dan Neonatal di Indonesia," Rakerkernas 2019, pp. $1-47,2019$.

[2] Kementerian Kesehatan RI Badan Penelitian dan Pengembangan, "Hasil Utama Riset Kesehatan Dasar," Kementrian Kesehat. Republik Indones., pp. 1-100, 2018, doi: 1 Desember 2013.

[3] M. M. Beckmann and O. M. Stock, "Antenatal perineal massage for reducing perineal trauma," Cochrane Database Syst. Rev., vol. 2013, no. 4, 2013, doi: 10.1002/14651858.CD005123.pub3.

[4] S. N. Rochmayanti and K. Ummah, "Pengaruh pijat perineum selama masa kehamilan terhadap kejadian ruptur perineum spontan," vol. 10, no. 1, 2018.

[5] H. Mutmainah, D. Yuliasari, and A. Mariza, "Pencegahan Rupture Perineum pada Ibu Bersalin dengan Pijat Perineum," J. Kebidanan, vol. 5, no. 2, pp. 137-143, 2019.

[6] Departemen Kesehatan RI kerjasama dengan WHO dan UNICEF, Buku Bagan Manajemen Terpadu Pijat Perineum Jakarta. 2014.

[7] I. B. G. F. M. Manuaba, I.B.G., I.A. Chandranita Manuaba, Episiotomi, dengan 
hubungan Pijat Perineum. Jakarta: Buku Kedokteran EGC, 2013.

[8] Hikmawati Isna, Pendidikan kesehatan dalam promosi Kesehatan. Yogyakarta: Nuha Medika, 2015.

[9] A. D. Suhendra, R. D. Asworowati, and T. Ismawati, "PENGETAHUAN, MOTIVASI IBU HAMIL TRIMESTER III TERHADAP PIJAT PERINEUM PADA IBU HAMIL," Akrab Juara, vol. 5, no. 1, pp. 43-54, 2020.

[10] R. W. Purnami and R. Noviyanti, "Effectiveness of Perineal Massage During Pregnant Women on Perineal Laseration," J. Kesehat. Madani Med., vol. 10, no. 2, pp. 61-68, 2019, doi: 10.36569/jmm.v10i2.41.

[11] Hala Abd El fttah Ali, "Effects of Prenatal Perineal Massage and Kegel Exercises on the Integrity of Postnatal Perine," Health (Irvine. Calif)., vol. 7, no. 4, pp. 495-505, 2015, doi: 10.4236/health.2015.74059. 